\title{
UMESTADISTA SENSITIVO. A noção de formação e o papel do literário em Minha formação, de Joaquim Nabuco
}

\section{Italo Moriconi}

$\mathrm{Na}$ história cultural brasileira, a figura de Joaquim Nabuco ora serve de modelo, ora é vista como sintoma. Na cultura canônica ainda não balizada pelos valores do modernismo de 22, Nabuco é um "founding father", paradigma de brasilidade. Assim o tratam intérpretes como Gilberto Freyre, Alceu Amoroso Lima, entre outros. A evocação com que Alceu Amoroso Lima abre, em 1965, seu notável prefácio a uma das edições de Minha formação projeta a figura de um absoluto. Eis o que escreve o já então veterano ideólogo e crítico literário:

Só vi Joaquim Nabuco uma vez na vida: de relance e na adolescência. Mas bastou para que ficasse gravada, para sempre, em minha retina, a imagem mais fulgurante do humanismo brasileiro em sua encarnação pessoal. Vi-o antes de lê-lo e, quando o li, revi-o tal qual o havia visto antes de o ler. O espírito e o corpo formavam nele uma unidade tão harmoniosa, que até hoje nenhum dos nossos compatriotas o excedeu. Nem mesmo se lhe equiparou. Continua solitário, único, inconfundível.

Foi em 1906. Tinha Nabuco então 57 anos de idade $[. .$.

O cenário do encontro não podia ser mais propício ao esplendor da revelação da mais bela flor masculina da nossa gente, já cercada de uma auréola de que o adolescente ouvira muito falar. Pois se reunia no Rio, por essa época, uma conferência Pan-Americana e Nabuco, nosso embaixador em Washington, participava naturalmente da nossa delegação. O cenário foi a praia de Botafogo, recentemente modernizada mas ainda totalmente deserta. Crepúsculo ainda claro. Ninguém na calçada do mar. Morando então ali por perto, na Rua Senador Vergueiro, costumava eu à tarde, vez por outra, ir passear o lirismo da adolescência já inquieta por aquelas avenidas novas, sem vivalma. Se os adolescentes de hoje levam consigo a angústia de viver acontecimentos que os abafam - nós já conhecíamos também, naquele tempo, uma inquietação contrária, a de viver uma época tão vazia de grandes acontecimentos...

[...] vejo ao longe dois vultos que se aproximavam [...] logo reconheci Eliah Root, o famoso delegado norte-americano e o nosso Nabuco. Fiquei siderado. O busto alevantado [...] um rosto aberto, iluminado por dentro de uma luz interior que completava a luminosidade do crepúsculo nos cabelos, olhos serenos e olímpicos, o chapéu, indispensável na época, mas na mão, o que já 
representava uma audácia [...] Em tudo uma grandeza, uma serenidade, uma harmonia, uma paz e tanta simplicidade humana que até hoje, quando me sinto perturbado e duvidoso de nossa gente, volto depressa àquela imagem imorredoura em minha memória, e retomo o caminho da confiança em nosso futuro. Nabuco continua a ser, para mim, o grande reconciliador nas horas de dúvida e desalento. Um país que produziu um exemplar humano como aquele, na mais bela harmonia de corpo e espírito, não pode deixar de ir para a frente e para o alto! (Lima, 1965, pp. 6-7)

A leitura de 22 contrasta com essa, lutando por outra visão. Em lugar da modernidade urbanística e desértica, estilo Brasília, vazio a ser preenchido por olhos voltados "para a frente e para o alto", o cenário da leitura que patologiza o até então modelar Nabuco é habitado ou contaminado pelas vozes interiores, arcaicas, atávicas, plurais, das tradições populares e multirraciais. Do sublime nacional, busto alevantado destacando-se contra o brônzeo crepúsculo, parte-se para o nacionalpopular, coletividade a ser compreendida e redimida pela cultura intelectual. A visão de uma nacionalidade sublime e ainda inteiramente por fazer segundo moldes da civilização passa a ser sintoma de alienação. De modelo da nacionalidade, Nabuco vira exemplo de patologia nacional. Em texto apresentado em recente simpósio sobre Nabuco, Luiz Costa Lima apresentou uma leitura que reativa em diferença tal sistema retórico, através da noção de "trauma da escravidão". ${ }^{1}$ Desde logo, deixo claro que considero esse tipo de leitura, modernista e pós-modernista, vamos chamá-la de sintomal, ainda hoje a mais rentável, na verdade o único ou o mais plausível caminho para a apropriação da vida-obra de Nabuco no interesse de uma crítica cultural (cultural critique). Em estudos culturais, todo signo é sintoma. Particularmente o signo autobiográfico.

A fórmula original, cômica e informal da imagem de Nabuco como sintomática vem de Mário de Andrade, que falava na "doença de Nabuco", na "moléstia de Nabuco". Como nos lembrou Flora Süssekind no mesmo simpósio, foi Silviano Santiago quem chamou a atenção da atual geração (universitária) de leitores para a riqueza da boutade de Mário. Simplificando, a "moléstia de Nabuco" é uma metáfora sobre o eurocentrismo cultural. É a fixação em procurar todos os modelos inspiradores de produção intelectual e artística lá do lado europeu, lá do lado do que chamamos popularmente de primeiro mundo. Este que para nós é o primeiro, para Nabuco era simplesmente $\mathrm{O}$ Mundo. A metáfora da moléstia de Nabuco é portanto índice de uma pedagogia centrada num paradigma que teoriza e pratica a formação como implantação no Brasil de valores civilizatórios europeus e norte-americanos selecionados em função de sua universalidade. Como aponta Nabuco em Minha formação, dos europeus e de nossos primos louros do Norte não nos interessam aqueles valores reconhecidos como particularistas deles. A formação é eurocêntrica mas pressupõe sucessivos atos de escolha por parte do membro da mais aquinhoada elite senhorial brasileira. Tal escolha exige o exercício intelectual e estético de uma permanente avaliação daquilo que pode ser dado como universal. Onde se lê universal, leia-se: passível de ser transferido, adaptado e aclimatado na realidade brasileira.

Tendo isso em vista, balizemos aqui a sintomatologia de Nabuco por duas fórmulas. Uma, do modernista Mário de Andrade: "moléstia de Nabuco”. Outra, do pós-modernista malgré lui-même, Luiz Costa Lima: Nabuco portador de um "trauma da escravidão”. São fórmulas que compartilham o viés da patologização, mas dizem respeito a dimensões distintas, porém, como argumentarei, complementares na economia textual de Minha formação. Sabemos bem que o pós-modernismo de Costa Lima, se realmente existe, traz embutido uma boa dose de anti-modernismo (de anti-22, para sermos mais precisos), de modo que sua fórmula ao mesmo tempo repete e critica aquela de Mário Andrade. Se Mário patologiza a figura modelar de Nabuco em função de um elogio do nacional-popular, Costa Lima mobiliza a retórica da patologização para rejeitar o que considera conseqüências negativas desse elogio, dessa ideologia.

O diagnóstico da "moléstia de Nabuco" foi pinçado por Silviano Santiago das cartas de Mário 
de Andrade a Drummond. Em sua leitura, Silviano (1996) articula as lições de brasilidade de Mário a uma arqueologia mais ampla da crítica ao eurocentrismo cultural operada pelo modernismo de 22. Nas cartas examinadas por Silviano, Mário defronta-se com o cosmopolitismo ingênuo e provinciano de Drummond, que em missiva anterior lamentara ter nascido entre "paisagens incultas" e "céus pouco civilizados". "Acho o Brasil infecto", declarara bombasticamente o então aprendiz de poeta. No trecho citado por Silviano, lemos que Mário detecta a origem de tamanho nojo na "tragédia de Nabuco de que todos sofremos”. A metáfora bemhumorada se estabelece em analogia com a doença de Chagas. Ambas são males bem nacionais, mas contra as duas os brasileiros já têm ciência suficiente para fazer o diagnóstico e curar. No campo da doença cultural, a reforma do olhar e dos sentimentos proposta pelo modernismo paulista pode trazer o antídoto capaz de neutralizar a moléstia de Nabuco. Escreve Silviano: "a dita tragédia de Nabuco nada mais seria que uma outra doença tropical, transmitida aos jovens pelo bacilo das ninfas européias” (Santiago, 1996, p. 41). E cita a formulação definitiva de Mário:

Moléstia de Nabuco é isso de vocês [brasileiros] andarem sentindo saudade do cais do Sena em plena Quinta de Boa Vista e é isso de você falar dum jeito e escrever covardemente colocando o pronome carolinamichaelismente. Estilize a sua fala, sinta a quinta de Boa Vista pelo que é e foi e estará curado da moléstia de Nabuco. (apud Santiago, 1996, p. 41)

A boutade de Mário refere-se a passagens do muitas vezes citado capítulo IV de Minha formação, intitulado "Atração do mundo", utilizadas como ponto de partida para os argumentos de Silviano Santiago no ensaio aqui comentado. Releiamos, pois, o próprio Nabuco (1999, p. 44):

Sou antes um espectador do meu século que do meu país; a peça é para mim a civilização, e se está representando em todos os teatros da humanidade, ligados hoje pelo telégrafo [...] em 1870, o meu maior interesse não está na política do Brasil, está em Sedan. No começo de 1871, não está na formação do gabinete Rio Branco, está no incêndio de Paris [...]

Para curar essa postura de observador alienado, emotivamente engajado apenas nos conflitos e acontecimentos metropolitanos, e desengajado do possível drama desenrolado a seu redor, o discurso modernista, como nos mostra Silviano, propõe um tipo de formação diferente, girando em torno de dois eixos: por um lado, enfrentar o passado nacional para transformá-lo em tradição válida e assim referi-lo ao presente; por outro, abrir-se aos saberes populares e multirraciais capazes de confrontar-se como fator de cultura aos valores exclusivamente europeus. Escreve Silviano Santiago (1996, p. 41):

$\mathrm{Na}$ década de 20, os modernistas afirmam que a superioridade da Europa, quando reconhecida e mimetizada pelo intelectual brasileiro, levava-o a encarar a coisa brasileira por dois pólos opostos, também complementares: por um lado, a corrente nativista idealizava o autóctone como puro e indomável (o índio e a paisagem, por exemplo) e, por outro lado, a corrente cosmopolita recalcava o que era produto do processo sócio-histórico de aclimatação da Europa nos trópicos (o mulato e a arte barroca de Aleijadinho, por exemplo).

Se o vocabulário modernista da "moléstia de Nabuco" encontra apoio no por todos os títulos famoso capítulo IV de Minha formação, "Atração do mundo", a formulação de Costa Lima, o "trauma da escravidão", encontra sua manifestação lapidar no capítulo XX, "Massangana" (nome do engenho onde Nabuco passou sua primeira infância). Se o capítulo IV de Minha formação contém uma formulação paradigmática da pulsão cosmopolita e eurocêntrica da cultura da elite brasileira no século $\mathrm{XIX}$, no capítulo XX o recalcado retornará com uma força impressionante. Pois em "Massangana" Nabuco confessa ter sido tomado, depois da Abolição, pelo surpreendente sentimento que ele chama de "saudade do escravo". Uma "singular nostalgia" que, ele mesmo reconhece, "muito espantaria um Garrison ou um John Brown”, dois de seus 
inspiradores anglo-saxônicos na longa cruzada antiescravista que marcara sua vida de parlamentar desde o ano de 1879 até a vitória em 1888, logo seguida da derrota advinda com a queda da Monarquia, que ocasionara sua retirada da vida pública. Retirada que se revelou temporária, pois, como se sabe, Nabuco acabou por aceitar servir à República no papel de diplomata, tornando-se um elemento de apoio à idéia da integração pan-americana e à doutrina Monroe. Seja como for, no momento em que publica na imprensa os capítulos autobiográficos daquilo que em seguida redundaria no livro Minha formação, Nabuco encontra-se frustrado e deprimido, ao ver que tinha realmente sido impossível preservar a instituição monárquica após a derrocada final do sistema escravocrata.

Nada mais característico do processo de aclimatação européia em solo americano meridional que o sistema escravocrata. É a sobrevivência de toda a cultura formativa associada a esse sistema que aparece tematizada em "Massangana". E é a esta sobrevivência que Luiz Costa Lima se refere quando fala em "trauma da escravidão". Por trauma da escravidão deve-se entender a permanência de um complexo de valores e afetos que, segundo ele, impedem a institucionalização de uma cultura crítica em nosso país, para além inclusive das alegadas limitações materiais advindas de nossa posição economicamente subalterna no capitalismo global. Na visão de Costa Lima (1999), não se trata de superar o eurocentrismo cultural e sim de enfrentar os traumas e bloqueios enraizados em nossa própria tradição. Se o desrecalque valorativo de nosso passado colonial nos restitui Aleijadinho, também nos joga na cara a herança de relações sociais incompatíveis com os princípios universais (e eurocêntricos...) de justiça, democracia e cidadania.

Ora, esse assunto dá pano para manga e pode-se dizer que todo o debate cultural brasileiro foi por ele marcado, desde o século passado, passando pelos modernismos de 22 e após, pelo marxismo e suas veredas entre os anos 30 e 70 e finalmente pelo neoculturalismo contemporâneo. Não pretendo nestas páginas estender-me sobre tão amplo espectro de posições. Apenas destaco o caráter estruturante desempenhado no texto de
Minha formação pela dualidade entre eurocentrismo e nostalgia da escravidão. Nesse sentido, os capítulos IV e XX, "Atração do mundo" e "Massangana", demarcam os dois lugares ausentes que funcionam como pólos magnetizadores do texto. Saudades da mãe Europa ou do pai ianque quando no Brasil, saudades do Brasil quando na Europa, no Mundo. Sina de intelectual brasileiro. Esses pólos dominam o discurso autobiográfico de $\mathrm{Na}$ buco, cristalizados nos dois capítulos cruciais que se opõem e ao mesmo tempo se completam como retrato do todo contraditório que compõe o sistema ideológico e valorativo da classe senhorial brasileira. Em "Atração do mundo", o pólo da relação com o mundo lá fora, com a civilização. Em "Massangana", o voltar-se para dentro de si, o reconhecimento de uma identidade cultural em que viceja a nostalgia da escravidão. A adesão aos princípios civis e civilizatórios ocidentais apenas recalca, mas não consegue eliminar determinações afetivas enraizadas na infância rural.

Como não mencionar aqui outro texto matricial no pensamento intelectual brasileiro do século 19, a saber, "O instinto de nacionalidade", de Machado de Assis. A dualidade que identificamos como eixo ideológico em torno do qual gira o discurso autobiográfico de Nabuco se apresenta no ensaio machadiano nos termos da conhecida contraposição complementar entre as noções de "influxo externo" e "sentimento íntimo". Sabemos que Machado busca contrapor-se a um conceito estético de nacionalidade basicamente indianista. De um lado, aponta para o caráter indescartável do influxo externo - nós brasileiros ainda não teríamos, naquele momento, condições civilizacionais para produzir formas originais de arte. De outro lado, segundo Machado, o nacional haveria de aparecer naturalmente em nossa literatura e não dependeria de fatores ornamentais externos, como cor local, descrições de tacapes e matas etc. O nacional para Machado seria dado por aqueles elementos emanados do sentimento íntimo, que haveriam de permear as formas estéticas, alienígenas apesar de universais. Caberia também mencionar a formulação de Antonio Candido, que, apesar da proximidade até mesmo afetiva deste "founding father" da doxa uspiana com o modernismo mário- 
andradino, a equacionou em termos mais próximos do ensaio original de Machado, esclarecendo, porém, o caráter histórico e polêmico-ideológico da polaridade mencionada, ou seja, destacando que as gerações e indivíduos atuantes em nossa vida intelectual ora pendem para um ora para outro pólo. Dualidade entre "cosmopolitismo" e "localismo", a fórmula de Candido (1985).

Mas volto ao modelo, para concluir o presente ponto. Observamos que a "formação" sobre a qual fala Joaquim Nabuco em seu relato autobiográfico apresenta uma dualidade, uma dobra. Por um lado, ela é "formação" no sentido de educação formal, aquisição dos valores eurocêntricos, processo em que a formação do indivíduo da elite é a condição pela qual se pode dar também a formação da nacionalidade. Assim, o pólo "atração do mundo" da formação pode ser lido tanto na clave do sistema de automodelagem da Bildung iluminista quanto na do tema elaborado pela tradição de pensamento da USP, no sentido de formação bistórica de nosso país enquanto país novo. ${ }^{2}$ Por outro lado, no pólo "massangana", o pólo "menino de engenho", formação pode ser lido como "romance de formação", no sentido de romance de família, conjunto de narrativas constitutivas e ordenadoras dos fantasmas e afetos individuais, os quais, na sua dobra social, remetem à herança, àquilo que vem de longe, àquilo que o Brasil já é, antes mesmo de se projetar para o futuro no seu desejo de civilizar-se, um desejo estratégico que só é consciente entre os membros da classe senhorial. A formação propriamente dita, ou civilização, algo adquirido por esforço construtivo e consciente, e o romance de formação, herança afetiva e genealógica impressa como tatuagem no corpo e na mente, constituem os dois pólos determinantes do conceito geral de formação tal como trabalhado no discurso autobiográfico de Joaquim Nabuco.

\section{A literatura e suas interfaces}

Quando nos detemos no papel assumido pela literatura em Minha formação, verificamos que não é tão simples, como talvez nosso olhar esquematizante pudesse querer fazer crer, a relação entre civilização e romance de formação na
Bildung modelar do homem público brasileiro oitocentista. Não existe uma pureza no influxo externo. Como já vimos, ele é sempre filtrado pelos atos de seleção destinados à reprodução e sobrevivência da classe senhorial, que significa a sobrevivência da própria Nação, pois esta, enquanto projeto corporificado num Estado, só interessa mesmo e diz respeito apenas a essa classe. E também não existe uma pureza de "sentimento íntimo", a não ser num nível muito básico de pura afetividade. No caso de Joaquim Nabuco, a evocação das fontes mais arcaicas desse sentimento passa pelo exercício literário e este tem como sua língua apropriada o francês, não o português. $O$ sentimento íntimo de Nabuco é bilíngüe, assim como os escravos que ele evoca em sua primeira infância como menino no engenho de Massangana são bilíngües, pois amoldam ou justapõem o português às línguas africanas. A língua européia para o membro da elite, a língua africana para o escravo. O fato de não existir uma língua brasileira estável leva a uma situação em que os pólos anteriormente identificados se interpenetram e até se equivalem em certos níveis. Se o pólo da formação estrito senso representa a aquisição de linguagem, bilíngüe desde sempre entre a língua local e a língua de civilização, a verdade é que o pólo do romance ou remete à ausência de linguagem ou também ele já é bilíngüe de saída. Esse bilingüismo inerente à formação social brasileira no século passado talvez explique o raciocínio por equivalências entre opostos e os jogos antitéticos típicos das retóricas dominantes nesse universo discursivo, a "girândola das contradições” de que fala Antonio Candido (1963) para referir-se ao funcionamento da linguagem em Sílvio Romero.

Como não podia deixar de ser, a literatura exerce o papel de cimento e instrumento de interpenetração entre as dimensões apenas aparentemente distintas na girândola das contradições. Não podia deixar de ser assim porque já a base humanista-renascentista do paradigma geral político-pedagógico da Bildung iluminista européia tem na literatura e na estética o ponto de apoio para a totalização dos discursos nos planos da moral, do afeto e da política. É por intermédio da cultura literária que se constrói a perspectiva 
abrangente capaz de estruturar o olhar cosmopolita e superior (no sentido de panóptico) do homem público educado. $\mathrm{Na}$ modernidade ocidental, particularmente aquela em que uma estrutura parlamentar constitui um eixo fundamental do poder (tal é efetivamente o caso do Brasil oitocentista), o homem público de primeiríssimo escalão deve necessariamente ser também um homem de letras, que significa dizer, um homem dotado das qualidades humanistas sem as quais não pode falar nem legislar em nome de todos e para todos, aí incluídas agora tanto a pequena burguesia e classe média urbanas quanto a escravaria das senzalas e a população negra liberta, que ocupa os interstícios do espaço social, os entrelugares.

Antes de ser político, Nabuco passa pelo estágio das letras. Ao passar por tal estágio, adquire uma patente que jamais dele se despregará. $\mathrm{O}$ homem público brasileiro neste molde clássico pode abandonar ou secundarizar a vida literária em detrimento de tarefas ligadas ao Estado, mas jamais abandona a idéia de que sua qualidade mais profunda, mais autêntica, aquele lado de si próprio de que ele mais gosta e mais se orgulha é o literário. Darcy Ribeiro ou José Sarney são manifestações de um tipo profundamente enraizado na definição do perfil do homem de poder em nossa civilização senhorial. Como observou pioneiramente Antonio Candido (1985), os indivíduos de nossa elite oitocentista são doublés de intelectual e político, no sentido de que não há intelectuais que não sejam políticos, embora obviamente a recíproca não seja verdadeira.

A tematização das relações com a literatura está presente em todos os momentos do texto de Minha formação, mas existem três capítulos especificamente dedicados a ela, os de número VII ("Ernest Renan”), VIII (“A crise poética") e IX ("Adido de legação"). Para quem como eu está preocupado em definir o lugar do literário no quadro da formação em geral, são capítulos riquíssimos por trazerem de maneira explícita uma série de valores e idéias que se tornaram clichês, servindo, por isso mesmo, como retrato fiel da ideologia literário-pedagógica prevalecente à época e que hoje nos parece uma relíquia exótica. Mas Nabuco não fica só nisso. Se como crítico ele se revela mero repetidor de clichês, por outro lado, nesses capítulos ele relata com sinceridade sua constatação de que não tinha talento literário, talento para poeta, embora muito se tivesse empenhado nesse projeto em sua primeira juventude. Temos aí um dos momentos, grandiosos, de auto-exposição de fragilidade que pontuamo texto de Minha formação. No capítulo VIII, ele reconhece um fracasso. Fracassou como poeta. Poeta em francês, ça va sans dire....

Mas o interessante na tematização do literário em Minha formação, além do valor documental (ao expor com clareza o clichê) e do valor exemplar em se permitir uma performance de fraqueza, está no que se segue, está na tentativa que Nabuco faz de entender de que maneira o literário alimentou toda sua relação com o estético e qual o papel da estética na conformação de sua personalidade política. Joaquim Nabuco esboça uma noção de estético-político extremamente interessante, produzida na confluência entre olhar panóptico, visão vertiginosa e a profunda crise político-existencial vivida por este homem de poder no momento da escrita de Minha formação. A lucidez manifesta nos capítulos VIII e IX contrasta novamente com "Massangana", em que a apreensão panóptica das coisas se vê abafada pela pura e simples expressão de uma profundidade que assoma como emoção. Estruturalmente falando, "Massangana" é o ponto de fuga do texto de Minha formação, fazendo contraponto primeiro ao capítulo "Atração do mundo" e, mais adiante, como vemos aqui, à referida tríade de capítulos sobre o literário.

Recapitulemos de maneira bem sucinta a seqüência de argumentos alinhavados na tríade. $\mathrm{Na}$ narrativa de Minha formação a vontade literária se enraíza no "húmus" (expressão do próprio Nabuco) das primeiras leituras dos tempos de estudante e em seguida define a primeira fase de um período diletante ("lazaronismo intelectual", dirá Nabuco) quase todo passado no exterior, primeiro na França por conta própria e, depois de um breve interregno no Brasil, como funcionário diplomático, adido desfrutável, sucessivamente em Londres e em Nova Iorque. O período todo se estende de 1873 a 1879, quando, novamente no Brasil, Joaquim Nabuco é compelido a entrar para 
a carreira política, na qualidade de herdeiro do pai e beneficiário de seus esquemas de compadrio. Este é o período cuja narrativa e avaliação constituem o grosso do texto de Minha formação e que tem no capítulo IV, "Atração do mundo", seu ponto de partida. A fase exclusivamente literária ocorre na etapa francesa. Nabuco leva seu volume de versos em francês a Paris e dedica-se a procurar figuras ilustres em busca de reconhecimento e aceitação. O livro intitula-se Amour et Dieu. Consegue elogios escritos de ninguém menos que Ernest Renan e Georges Sand. Seria a Europa curvando-se ante o Brasil? Nem tanto. Depois de mais algumas tentativas no período londrino, Nabuco logo compreenderá que os elogios parisienses não tinham passado de meras formalidades. Inteligente que era, genuíno leitor que era, finalmente compreendeu que não tinha vocação para poeta e que Amour et Dieu era um livro ruim. Eis o que lemos no capítulo VIII:

O fato é que não possuo a forma do verso, na qual a idéia se modela por si mesma [...] que nenhum artifício nem esforço pode imitar. [...] Quanto à grande poesia, à poesia de imaginação e criação, poema, romance, balada que fosse, para essa eu seria incapaz, além da insuficiência do talento, pela falta de coragem para habitar a região solitária dos espíritos criadores, os quais vivem [...] sem vida própria, autômatos da sua inteligência e da sua vontade, como em um sonho acordado. (Nabuco, 1999, p. 73)

Diante disso, Nabuco desistirá de profissionalizar-se como artista. Conclui que é escritor, mas não poeta $\mathrm{e}$ nem artista (pois o fato de não ser poeta também não significava que em contrapartida lhe estivessem sendo facultados fôlego ou talento para a prosa ficcional). Sua desistência, porém, não representa reconhecimento ou elogio a um hipotético caráter diletante ou desinteressado da atividade literária. No capítulo VIII, Nabuco defende a profissionalização do escritor, artista ou não artista. $^{3}$ Segundo ele, a profissionalização deve se dar por meio do estudo sistemático da história como fundamento da atividade da escrita. Tanto o escritor artista, que Nabuco deixará de ser, quanto o escritor não-artista, que Nabuco se resigna a ser, só se tornam profissionais se se dedicam ao estudo da história. Declara Nabuco que esta foi a lição diretamente recebida de Renan na forma de conselho. Na verdade, o escritor não-artista devese tranformar em historiador tout court, algo que Nabuco considera ter finalmente conseguido pôr em prática ao escrever Um estadista do Império, a monumental biografia de seu pai, texto matricial para a compreensão de nosso século XIX sob o prisma do interesse senhorial.

O que sobra para a literatura depois da (previsível) renúncia à carreira de homem de letras e do mergulho irreversível na carreira de político nas três dimensões complementares abraçadas por nosso personagem - a de parlamentar, a de agitador/mediador do abolicionismo, a de historiador-memorialista de sua própria família? A fase literária, européia, e o lugar posterior do literário, uma vez ultrapassada a etapa diletante das viagens, justapõem-se no parágrafo final do capítulo VIII e nos indicam a resposta:

[...] eu trocara em Paris e na Itália a ambição política pela literária: voltava cheio de idéias de poesia, arte, história, literatura, crítica, isto é, com uma espessa camada européia na imaginação, camada impermeável à política local, a idéias, preconceitos e paixões de partido, isoladora de tudo o que em política não pertencesse à estética, portanto também do republicanismo - porque a minha estética política tinha começado a tornar-se exclusivamente monárquica. (Nabuco, 1999, p. 78)

O que me parece notável nesse trecho é o elo que Nabuco estabelece entre formação literária (necessariamente européia), estética e política, lançando ao final a idéia de "estética política". Ou seja, Nabuco não se refere a seu monarquismo nem como ideologia nem como escolha racional. É claro que seu monarquismo também é isso, mas o interessante a ressaltar é que para ele o plano de determinação mais primordial se dá no nível estético. Entre republicanismo e monarquismo, trata-se em primeiro lugar de opção estética, se encarada a questão sob o prisma do processo de formação do membro da elite. Observe-se ainda que a estética 
se coloca como a dimensão por excelência da interface, do cimento entre esferas diversas e conflitantes. É por meio da estética que Nabuco pode se religar à política local, da qual o afasta a mesma estética, enquanto particularizada na província literária.

Essas conexões retóricas, que são deixadas no texto de Minha formação como sugestões de relance, voltam a aparecer no capítulo seguinte, "Adido de legação", onde se lê:

A verdade é que, entre as molas do meu mecanismo, nenhuma teve a elasticidade e a força da que eu chamaria a mola estética.

[...] meus erros foram desvios de idealização; eu nunca teria podido confessar uma idéia, uma crença, um princípio, que não fosse para mim um ímã estético [...] Para sentir, sempre que a hasteei, a minha dignidade, a minha altivez, o meu espírito expandir-se, era preciso que o signo monárquico atuasse em mim, como uma parcela da arte que está misturada com a história e que de algum modo a diviniza. (Nabuco, 1999, pp. 79-80)

Nos parágrafos seguintes, vemos que para Nabuco existe uma "consciência estética" que molda uma visão de mundo a partir de formas ideais cujo poder de ordenamento do real moral e político é determinante porque se deposita no plano inconsciente. Ou seja, o estético é a dimensão que dá forma ao instinto afetivo. Nesse sentido, o estético opera a interface entre as duas dimensões da formação de que tratei na seção anterior. Ele se compõe do resíduo formal deixado pela dimensão cosmopolita e se enraíza no fundo mesmo do sentimento íntimo. Já no final do capítulo IV Nabuco produzira uma formulação razoavelmente satisfatória deste sistema de autocompreensão:

Cada um de nós é só o raio estético que há no interior do seu pensamento, e, enquanto não se conhece a natureza desse raio, não se tem idéia do que o homem realmente é. Nesta confissão da minha formação política, devo, para não deixar ver somente a máscara, o personagem, dar uma espécie de fotografia dos símbolos que se impri- miram e reproduziram mais profundamente no meu cérebro. Assim se reconhecerá que a política não foi senão uma refração daquele filete luminoso que todos temos no espírito. (idem, p. 50) ${ }^{4}$

\section{De volta a Massangana: o trauma da escravidão}

Se o assunto é literatura, talvez o capítulo XX de Minha formação possa ser visto como o mais literário do livro. Aquele em que verdades nuas e cruas irrompem nas linhas e entrelinhas de uma linguagem comandada pela vontade de estilo. Não consigo resistir ao desejo de passar na íntegra ao leitor a seguinte página antológica da nossa literatura. Antológica como exemplo bem-sucedido de evocação descritiva - valor técnico. Antológica pelo fato de apresentar com nitidez a topografia do poder senhorial - valor mimético-documental. Trata-se do primeiro parágrafo de "Massangana". Vamos a ele:

O traço todo da vida é para muitos um desenho da criança esquecido pelo homem, mas ao qual ele terá sempre que se cingir sem o saber [...] Pela minha parte acredito não ter nunca transposto o limite das minhas quatro ou cinco primeiras impressões [...] Os primeiros oito anos da vida foram assim, em certo sentido, os de minha formação, instintiva ou moral, definitiva [...] Passei esse período inicial, tão remoto, porém mais presente do que qualquer outro, em um engenho de Pernambuco, minha província natal. A terra era uma das mais vastas e pitorescas da zona do Cabo [...] Nunca se me retira da vista esse pano de fundo que representa os últimos longes de minha vida. A população do pequeno domínio, inteiramente fechado a qualquer ingerência de fora, como todos os outros feudos da escravidão, compunhase de escravos, distribuídos pelos compartimentos da senzala, o grande pombal negro ao lado da casa de morada, e de rendeiros, ligados ao proprietário pelo benefício da casa de barro que os agasalhava ou da pequena cultura que ele lhes consentia em suas terras. No centro do pequeno cantão de escravos levantava-se a residência do senhor, olhando para os edifícios da moagem, e tendo por 
trás, em uma ondulação do terreno, a capela sob a invocação de São Mateus. Pelo declive do pasto árvores isoladas abrigavam sob sua umbela impenetrável grupos de gado sonolento. $\mathrm{Na}$ planície estendiam-se os canaviais cortados pela alameda tortuosa de antigos ingás carregados de musgos e cipós, que sombreavam de lado a lado o pequeno rio Ipojuca. Era por essa água quase dormente sobre os seus largos bancos de areia que se embarcava o açúcar para o Recife; ela alimentava perto da casa um grande viveiro, rondado pelos jacarés, a que os negros davam caça, e nomeado pelas suas pescarias. Mais longe começavam os mangues que chegavam até à costa de Nazaré [...] Durante o dia, pelos grandes calores, dormia-se a sesta, respirando o aroma, espalhado por toda a parte, das grandes tachas em que cozia o mel. O declinar do sol era deslumbrante, pedaços inteiros da planície transformavam-se em uma poeira de ouro; a boca da noite, hora das boninas e dos bacuraus, era agradável e balsâmica, depois o silêncio dos céus estrelados, majestoso e profundo. De todas essas impressões nenhuma morrerá em mim. Os filhos de pescadores sentirão sempre debaixo dos pés o roçar das areias da praia $\mathrm{e}$ ouvirão o ruído da vaga. Eu às vezes acredito pisar a espessa camada de canas caídas da moenda e escuto o rangido longínquo dos grandes carros de bois [...] (Nabuco, 1999, pp. 159-160)

Agregando-se aos valores técnico e mimético, este trecho possui também um valor canônico na história literária e cultural, por fornecer um clichê de tantos e tantos parágrafos encontráveis na literatura regionalista nordestina. Aproximando "Massangana" de uma evocação semelhante feita por Sílvio Romero em depoimento autobiográfico a João do Rio em 1905, Roberto Ventura (1991) observa que o engenho é um topos indicador de apego nativista e de saudade de uma infância idílica que aparece como tempo-lugar de uma relação sentimental e sem conflitos com os escravos. Assim como em Nabuco e em Romero, essa imagem compensatória de uma infância idílica se esboça num contexto histórico de ruptura entre a hegemonia do universo da grande propriedade rural e a nova economia mais urbana e centrada em torno da produção cafeeira no Centro-Sul. Acompanhando a interpretação clássica de Alfredo Bosi, Ventura lembra que o tema da decadência do mundo da grande propriedade rural patriarcal define uma constante que vai de Romero e Nabuco a Carlos Drummond de Andrade, passando por Gilberto Freyre, Sérgio Buarque de Hollanda, Cornélio Pena, Lucio Cardoso, José Lins do Rego, Graciliano Ramos e poderíamos estender a lista até autores mais contemporâneos, como Autran Dourado.

Desenvolvendo o elo levantado por Roberto Ventura, teríamos que em cada um desses autores, ficcionistas e ensaístas-intérpretes, a ruptura encontraria seu símbolo específico e a nostalgia se apresentaria dentro de uma singularidade. No caso de Minha formação, a ruptura se dá quando o menino Joaquim se vê obrigado a deixar Massangana, ao ser o engenho vendido a terceiros após a morte da grande senhora Ana Rosa, madrinha de Nabuco, figura legendária a quem Gilberto Freyre dedica alguns parágrafos em Sobrados e mucambos. A singularidade do modo como a questão da nostalgia aparece em Nabuco estaria justamente na formulação ambígua dessa nostalgia como trauma, situação indesejada porém insuperada. Nesse sentido, é onde se mostra mais cristalino o clichê que se apresenta também de maneira mais cabal o seu sentido subjetivo e histórico.

Voltemos à seqüência do capítulo. A evocação do passado infantil idílico reserva surpresas chocantes ao leitor contemporâneo, imbuído dos valores da cidadania e da autonomia individual, especialmente o leitor do hoje hegemônico Centro-Sul do país, muitas vezes oriundo de estoques culturais marcados por ondas mais recentes de imigração européia ou asiática e que portanto, apesar de brasileiro, sente-se completamente estrangeiro em relação ao tipo de quadro bucólico pintado por Nabuco. O leitor contemporâneo: este que no Sudeste, ainda por cima, já não conhece talvez mais nada que não a bruta e realista educação sentimental pautada pela objetividade das relações referidas ao mercado e a revolucionada plasticidade dos laços de família esgarçados.

Me pergunto se tal estranheza, provocada pela explicitação quase obscena da "síndrome de 
Massangana”, a nostalgia da escravidão, não seria uma estranheza inquietante, misto de pânico e identificação diante da conjuração de fantasmas que talvez permaneçam atuantes e inextirpáveis no romance de formação de qualquer intelectual e/ou político brasileiro. Será que nós, trabalhadores e produtores intelectuais, que não temos sobrenome de cepa lusitana, que fomos educados em escolas públicas nas grandes metrópoles e que em boa parte dos casos nos doutoramos em universidades laicas estrangeiras, será que nós também estamos irreversivelmente contaminados pelo trauma da escravidão? Será que nos tornamos mental e emotivamente "senhores feudais" mesmo no contexto de intensificação capitalista que marca o Brasil exatos cem anos depois da publicação de Minha formação?

Terá razão Luiz Costa Lima, que definiu a nostalgia da escravidão como trauma nacional, algo que precisa ainda ser superado por um esforço auto-reflexivo e autocrítico simultaneamente individual e coletivo?

Costa Lima apenas lança a idéia de que o trauma da escravidão estaria na raiz da ausência de pensamento crítico no Brasil, sem propriamente desenvolvê-la, restringindo-se a apontar o elo entre tal ausência e um genérico "sentimentalismo" resultante do trauma. Levanto aqui elementos que operam a partir dessa intuição importante, embora concorde apenas em parte com ela. Não subscrevo a idéia de que inexiste pensamento crítico no Brasil, apesar de também achar que ele nem de longe paute o funcionamento das instituições públicas no país (universidade, imprensa e mídia e política profissional). Mas a meu ver, o que o capítulo XX de Minha formação faz é simplesmente revelar limites de classe impostos ao pensamento crítico no quadro da formaçãa da elite oitocentista em nosso país.

Nessa linha, o que me parece frutífero como aprendizado possível de ser extraído de uma leitura de "Massangana", mesmo marcada pela estranheza e pela distância, é identificar o que exatamente impede o florescimento cabal do pensamento crítico numa dada configuração social e intelectual (vale dizer, formativa, ou ainda: político-pedagógica). Quase numa palavra, usando a boa gíria: os limites ao criticismo evidenciados pela tematização da nostalgia da escravidão são dados pela ausência total de semancol. Ou seja, ausência de autocrítica, naturalização de sentimentos, considerados intransponíveis porque dados como espontâneos e enraizados num plano afetivo prélingüístico, pré-formativo.

Não se trata de invalidar ou rejeitar sentimentos, muito menos desqualificar a noção de criação artística como expressão e análise de sentimentos. Pelo contrário, considero que a análise de sentimentos constitui uma das mais importantes funções do discurso literário nas condições em que contemporaneamente se dá a formação. Uma análise literária (ficcional ou não) de sentimentos (ficcional ou não) será tanto melhor quanto estiver associada a uma crítica de sentimentos. Criticar os próprios sentimentos é estar engajado em algum tipo de revolução existencial. Mais importante ainda é identificar por trás de valores e conceitos que nos parecem auto-evidentes sentimentos criticáveis ou no mínimo relativizáveis.

No capítulo "Massangana” existem tanto expressão quanto análise de sentimentos. Análise do elo afetivo que Nabuco ingenuamente acredita haver existido entre senhores e escravos no passado idílico dos engenhos de açúcar fechados em si. Mas não existe crítica de sentimentos. $O$ mais escandaloso para o leitor contemporâneo é que Nabuco elogia o desinteresse, a dedicação e a devoção que ele acreditava serem os fatores determinantes na relação do escravo com os senhores. Nabuco em "Massangana" se enternece com a lembrança de seus escravos como se falasse de animais de estimação. E embora a primeira versão deste capítulo de Minha formação tivesse sido um texto originalmente escrito em francês, Nabuco enfatiza que o sentimento por ele evocado é tão básico, tão genuíno, que se situa num plano de puro afeto, um plano sem palavras, um plano que permitia a comunicação pela pele para além da impossibilidade de comunicação lingüística entre o francês do senhor e o africano do escravo. Mais ofensiva ainda é a cena exemplar rememorada (ou inventada) por Nabuco, de um escravo que se joga a seus pés, ele criança com menos de oito anos, a implorar-lhe que interceda junto à todo-poderosa Madrinha para não ser vendido a outro senhor. 
Causa repugnância o fato de Nabuco comprazer-se sentimentalmente no papel de protetor dos fracos que lhe cabia como membro infante da classe senhorial.

O sentimento da proteção senhorial: eis algo a ser expresso, analisado, mas também rejeitado. Para que o pensamento crítico possa existir é preciso que estejamos preparados para extirpar pedaços de nós mesmos e que reconheçamos em nós mesmos o fascismo e a iniqüidade que tão facilmente identificamos nos outros.

Se o conteúdo dos sentimentos que Nabuco celebra em clave de retorno do recalcado me causa engulhos porque não me reconheço ideologicamente nesse Brasil primordial que ele idilicamente descreve, pois minha história é toda outra, por outro lado não posso deixar de reconhecer a grandiosidade do ato de Nabuco ao escrever "Massangana”. Grandiosidade intelectual, por não ter tido medo de se expor ao risco de desmoralização de toda a biografia de líder abolicionista que construíra ao longo de uma vida pública bastante influente numa fase do processo de construção do moderno Estado-Nação brasileiro. Nosso moderno Estado-Nação, hoje em vias de reciclar-se para uma nova história, a história futura que nos apontam o Mercosul e as integrações supranacionais - continental, ibérica, luso-africana, além da, por que não?, integração pan-americana em função da qual Nabuco trabalhou decisivamente, nos anos posteriores a Minha formação. São todas elas integrações necessariamente conflitantes e vividas diferencialmente pelos múltiplos grupos sociais e culturais. As relações vividas são emolduradas (framed) pelo Estado em transformação mas podem obedecer a lógicas outras que não apenas aquelas determinadas pela lógica da moldura. A integração pode se dar tanto em esferas de poder panóptico e totalizador, quanto no trânsito das trocas de múltiplos circuitos alternativos. Uma coisa é o Estado brasileiro associar-se a outros Estados em esquemas supranacionais. Outra coisa, para dar um único exemplo, é criar alianças entre movimentos negros brasileiros, caribenhos e norte-americanos. À globalização econômica seguem-se não apenas a globalização do governo mas também a globalização da sociedade civil.
Mas voltemos à literatura. Sobretudo, cabe destacar a qualidade literária do capítulo "Massangana" por realizar de maneira cabal o objetivo máximo, ainda hoje válido, traçado para o texto literário pela pena de Alencar, o oponente juvenil de Nabuco que este depois reconheceu ter estado coberto de razão na famosa polêmica. Pois para Alencar, tal como se pode ler por exemplo no prólogo de Iracema, o objetivo da ficção literária (e aqui proponho que se leia isso no sentido de ampliar o conceito de literário para abarcar tanto textos ficcionais quanto não ficcionais, como a autobiografia e o ensaio) é infundir vida aos valores e idéias abstratas, criando e conjurando em imagens (fantasmas) o sistema de sentimentos que lhes corresponde. Cabe ao discurso literário, entre outras coisas, desvelar os conflitos de sentimentos suscitados pelo domínio das racionalidades discursivas, sejam elas quais forem: a idéia de pátria no século XIX, a diáspora das subjetividades hoje.

Em "Massangana" Nabuco revela o complexo de sentimentos associado à idéia que ele foi pioneiro em veicular no Brasil e que seria retomada e desenvolvida por Gilberto Freyre: a idéia de que o sistema escravocrata era um mal que afetava irreversivelmente tanto escravos quanto senhores, enredando-os numa miríade de interesses libidinais comuns. A fisiologia dessa perversão é obscenamente exposta nas páginas simultaneamente altivas e melancólicas do capítulo "Massangana". O texto a um tempo sincero e falso de Nabuco (simplesmente não é possível acreditar no caráter idílico das relações de proteção) vale e continuará valendo por aquilo que se pode fazer com ele no ato da leitura. Não sei se para o alto. Mas para a frente, com certeza, estamos todos indo. Se para melhor ou pior, dependerá um pouco do acaso e um pouco de cada escolha e de cada decisão tomada, nos planos individual, grupal, nacional. A autobiografia de Nabuco pode ainda desempenhar um papel terapêutico e esclarecedor se for lida como alimento para a auto-reflexão crítica, ou seja, como incentivo à eliminação das autocomplacências e auto-evidências de qualquer tipo nos planos intelectual e político. 


\section{NOTAS}

1 Luiz Costa Lima, Joaquim Nabuco e a crítica literária, paper lido na mesa-redonda "Joaquim Nabuco e a Literatura”, do simpósio Repensando o Brasil com Joaquim Nabuco, onde foi apresentada também uma primeira versão do presente artigo. O simpósio foi organizado por Eduardo Portella e Beatriz Resende na Biblioteca Nacional, entre 29 de novembro e $1^{\underline{o}}$ de dezembro de 1999, como parte inicial do ciclo de eventos O Brasil $e$ seus intérpretes.

2 Sobre o tema da "formação" na tradição da USP, ver Arantes e Arantes (1997).

3 Interessante observar que, segundo Flora Süssekind, Nabuco defende ponto de vista diametralmente oposto a esse em Pensées detachées.

4 Tendo em vista o tema específico do presente ensaio, deixo de lado as conexões estabelecidas por Nabuco entre o ideal estético, a política e um terceiro termo também muito importante no universo retórico de Minha formação: a religião. Uma abordagem mais totalizadora das múltiplas conexões trabalhadas discursivamente por Joaquim Nabuco pode ser encontrada nos livros e escritos de Marco Aurélio Nogueira, sem dúvida alguma, na geração atual seu mais importante especialista e arguto leitor.

\section{BIBLIOGRAFIA}

ARANTES, Otília Beatriz F. e ARANTES, Paulo Eduardo. (1997), Sentido da formação. Rio de Janeiro, Paz e Terra.

CANDIDO, Antonio. (1963), O método crítico de Silvio Romero. 2a. ed., São Paulo, Universidade de São Paulo, Boletim n. 266.

. (1985), Literatura e sociedade. $7^{\text {a }}$ ed., São Paulo, Ed. Nacional.

LIMA, Alceu Amoroso. (1965), "Pró-memória: introdução a Minha formação", in Joaquim Nabuco, Minha formação, Rio de Janeiro, Tecnoprint.

LIMA, Luiz Costa. (1999), Joaquim Nabuco e a crítica literária. Paper apresentado na mesa-redonda "Joaquim Nabuco e a Literatura", do simpósio Repensando o Brasil com Joaquim Nabuco, Rio de Janeiro, Biblioteca Nacional, 29 de novembro a $1^{\circ}$ de dezembro.

NABUCO, Joaquim. (1999), Minha formação. Rio de Janeiro, Topbooks.

NOGUEIRA, Marco Aurélio. (1984), As desventuras do liberalismo - Joaquim Nabuco, a Monarquia e a República. Rio de Janeiro, Paz e Terra.
SANTIAGO, Silviano. (1996), "Atração do mundo: políticas de identidade e de globalização na moderna cultura brasileira”. Gragoatá, Niterói, Programa de Pós-Graduação em Letras da UFF/EdUFF, 2을 semestre: 31-54.

VENTURA, Roberto. (1991), Estilo tropical - bistória cultural e polêmicas literárias no Brasil. São Paulo, Cia das Letras. 